\title{
The Importance of Applying Parenting Education Program for The Student's Parent in Elementary School
}

\section{Anggit Putri Natasa, Rahma Arifah Ludfiani, Moh Salimi}

Universitas Sebelas Maret

anggitnatasa04@student.uns.ac.id

Article History

accepted 24/09/2019

approved 01/10/2019

published 01/12/2019

\begin{abstract}
Parents are the child's first mentors in the learning process at home. Some parents feel unable to guide children at home. Parenting Education Program (PEP) has the opportunity as a solution to help parents guide their children at home. This study focuses on the definition, application, benefits and importance of Parenting Education Programs. The results of this study include: (1) $P E P$ is a training program held by schools to provide guidance in the form of knowledge and skills to parents; (2) The application of PEP has been applied in several elementary schools, namely SDIT Ar Raihan Bantul, SD Surya Buana Malang and SD Insan Teratai Tangerang; (3) The benefits of PEP are establishing a good relationship between school and parents, increasing parental knowledge and increasing parental confidence; (4) PES is important to be implemented in many elementary schools that do not directly involve parents in children's education
\end{abstract}

Keywords: Parenting Education Program, Parents, Elementary School

\section{Abstrak}

Orangtua merupakan pembimbing pertama anak dalam proses belajar di rumah. Beberapa orangtua merasa tidak mampu membimbing anak di rumah. Parenting Education Program (PEP) berpeluang sebagai solusi membantu orangtua dalam membimbing anak di rumah. Kajian ini fokus pada definisi, penerapan, manfaat dan pentingnya Parenting Education Program. Hasil kajian ini meliputi: (1) PEP merupakan program pelatihan yang diadakan oleh sekolah untuk memberikan bimbingan berupa ilmu pengetahuan dan keterampilan kepada orangtua; (2) Penerapan PEP telah diterapkan di beberapa Sekolah Dasar yaitu SDIT Ar Raihan Bantul, SD Surya Buana Malang dan SD Insan Teratai Tangerang; (3) Manfaat PEP adalah menjalin hubungan yang baik antara sekolah dan orangtua, meningkatkan pengetahuan orangtua dan meningkatkan percaya diri orangtua; (4) PEP penting diimplementasikan pada banyak Sekolah Dasar yang belum melibatkan orangtua dalam pendidikan anak secara langsung.

Kata kunci : Parenting Education Program, Orangtua, Sekolah Dasar

Social, Humanities, and Education Studies (SHEs): Conference Series https://jurnal.uns.ac.id/shes 


\section{PENDAHULUAN}

Pendidikan adalah usaha sadar untuk menyiapakan peserta didik melalui kegiatan bimbingan, pengajaran, pengawasan, dan atau latihan bagi perannya dimasa yang akan datang. Pendidikan bisa dijadikan wadah bagi seseorang untuk berkembang dalam berbagai segi kehidupan. Pendidikan merupakan salah satu bagian terpenting dari kehidupan manusia, dengan pendidikan yang lebih tinggi diharapkan akan manghasilkan manusiamanusia yang lebih berkualitas (Afrianto, 2011: 69). Dari berbagai jenjang pendidikan, Sekolah Dasar merupakan jenjang pendidikan yang paling krusial, dimana karakter dan kepribadian anak akan terbentuk. Terdapat beberapa faktor penentu keberhasilan pendidikan anak di sekolah yaitu guru, orangtua dan lingkungan. Orangtua memiliki peranan terpenting dalam menentukan keberhasilan pendidikan anak.

Pendidikan keorangtuaan (parenting) adalah sebuah proses memanfaatkan keterampilan mengasuh anak yang dilandasi oleh aturan-aturan yang agung dan mulia (Ilahi, 2013). Orangtua sebagai orang terdekat dengan anak mempunyai peran penting dalam pemberian bimbingan dan arahan terhadap perkembangan anak. Anak akan lebih cepat merespon apa yang diajarkan dan disampaikan oleh orangtua. Pola asuh orangtua terhadap anak akan sangat mempengaruhi tingkah laku anak. Parenting ialah bentuk kegiatan informal yang dilakukan untuk menyelaraskan kegiatan-kegiatan pengasuhan dan pendidikan anak antara di kelompok bermain dan di rumah (Harahap, 2012). Pendampingan belajar oleh orangtua sangatlah penting dalam meningkatkan kualitas belajar anak di rumah yang nantinya akan mempengaruhi prestasi anak saat di sekolah. Menurut Tanta (2010), peran orang tua dalam memberikan pendidikan yang terbaik bagi anak-anaknya, memang tidak perlu diragukan lagi. Banyak keterlibatan orang tua dalam mendukung pendidikan anak-anaknya, salah satunya adalah melakukan pendampingan terhadap anak dalam belajar di rumah.

Peran orangtua dalam mendukung pendidikan anak disebutkan dalam salah satu pasal Permendikbud No. 23 Tahun 2015 tentang penumbuhan budi pekerti. Pada pasal 3 Permendikbud tersebut disebutkan bahwa sekolah hendaknya melibatkan orangtua dan masyarakat dalam proses penumbuhan budi pekerti yang dilakukan di sekolah. Keterlibatan ini diharapkan akan berbuah dukungan orangtua dalam berbagai bentuk. Salah satunya adalah Orangtua harus berperan aktif dalam memberikan pengawasan dan bimbingan kepada anak agar belajar anak menjadi berkualitas. Pentingnya peran orang tua dalam pendidikan juga tercantum dalam Undang-Undang Nomor 20 Tahun 2003 tentang Sistem Pendidikan Nasional Pasal 7, Ayat 1 yang berbunyi, "Orangtua berhak berperan serta dalam memilih satuan pendidikan dan memperoleh informasi tentang perkembangan anaknya".

Meskipun pelibatan orangtua di sekolah penting, tetapi masih banyak sekolah yang belum melaksanaka kebijakan pemerintah berdasarkan Undang - Undang secara optimal. Sekolah kadang menutup diri dari campur tangan orangtua dalam proses pendidikan anak di sekolah (Syamsudduha dan Dion G, 2016). Orangtua hanya dihadirkan ketika akan menerima rapor, atau pada saat akan meminta bantuan pembiayaan di sekolah. Komunikasi dan diskusi tentang bagaimana pola pendidikan anak sangat jarang dilakukan, bahkan tidak pernah.

Berdasarkan Penelitian yang dilakukan oleh Cholifah (2016) yang berjudul Pengaruh Latar Belakang Tingkat Pendidikan Orangtua Dan Gaya Belajar Terhadap Hasil Belajar Siswa Pada Kelas IV SDN Kecamatan Sananwetan Kota Blitar menunjukkan bahwa latar belakang tingkat pendidikan orangtua mempunyai pengaruh terhadap hasil belajar siswa, orangtua akan memiliki pendidikan yang baik maka akan berdampak pada hasil belajar siswa yang meningkat. Hal ini dapat dipahami bahwa semakin tinggi latar belakang tingkat pendidikan orangtua maka dapat memberikan manfaat untuk pendidikan siswa agar menjadi lebih baik lagi. 
Tidak semua orangtua di Indonesia memiliki riwayat pendidikan yang tinggi, masih banyak ditemukan orangtua yang memiliki riwayat pendidikan yang rendah. Berdasarkan data dari Dinas Kependudukan dan Pencatatan Sipil Kabupaten Grobogan menyatakan bahwa komposisi tingkat pendidikan penduduk tertinggi ditempati kateogori tamatan Sekolah Dasar atau sederajat sebesar $43 \%$. Hal tersebut sangat mempengaruhi pendidikan anak. Anak tidak akan mendapatkan pendidikan yang baik saat dirumah apabila orangtua tidak mampu memfasilitasi anak dalam hal pengetahuan maupun pola asuh. Hal tersebut terjadi apabila dalam proses belajar dirumah anak mengalami kesulitan sehingga akan bertanya kepada orang tua.karena terbatasnya kemampuan yang dimiliki orang tua, akan membuat proses belajar anak menjadi salah. Selain itu, juga ditemukan orangtua yang lebih memilih untuk menempatkan anaknya ke bimbingan belajar untuk mengganti kegiatan belajar anak saat dirumah. Orang tua merasa kurang mampu memfasilitasi anak dalam belajar sehingga lebih mempercayakan anak masuk bimbingan belajar yang akan dibimbing oleh orang yang lebih professional. Padahal, pada bimbingan belajar belum mengetahui secara penuh bagaimana karakter anak tersebut sehingga hanya melakukan bimbingan secara umum.

Banyak cara yang dilakukan untuk mempersiapkan orangtua dalam mengasuh anak saat dirumah. Parenting Education Program atau sekolah orangtua merupakan jawaban permasalahan orangtua yang masih belum tau cara dalam mengasuh anak di rumah. Sekolah orangtua bisa dilaksanakan oleh pihak sekolah yang akan memberikan pelatihan kepada orangtua dalam hal pengetahuan dan pola asuh. Kegiatan pelatihan dilaksanakan oleh guru maupun mendatangkan seorang ahli yang dilaksanakn di sekolah. Dalam Parenting Education Program akan membahas bagaimana pola asuh anak yang baik dan memberikan orangtua beberapa materi dasar yang diajarkan oleh guru kepada anak serta beberapa keterampilan dasar yang bisa diterapkan orang tua kepada anak saat dirumah. Pelaksanaan Parenting Education Program sudah dilaksanakan oleh beberapa Sekolah dasar yang ada di Indonesia, yakni SDIT Ar Raihan Bantul (Endarti, 2019), SDI Surya Buana Kota Malang(Lindasari, 2017) dan SD Insan Teratai(Septiani, 2016).

Artikel ini membahas mengenai pelaksanaan program Parenting Education Program sebagai salah satu program dalam membantu orangtua dalam mengembangkan kemampuan yang dimiliki di SDIT Ar Raihan Bantul, SDI Surya Buana Kota Malang dan SDIT Lukman Al Hakim Internasional Yogyakarta. Diharapkan, melalui pengetahuan ini, orangtua maupun pihak sekolah memiliki kesadaran akan pentingnya pelaksaan sekolah orangtua diterapkan untuk mendekatkan pihak sekolah dan orangtua serta memberikan pelatihan bagaimana pola asuh terhadap anak dengan baik.

Berdasarkan paparan tentang permasalahan orangtua dalam membimbing anak di rumah dan kebutuhan atas penerapan Parenting Education Program. Maka dibutuhkan kajian tentang pentingnya penerapan Parenting Education Program untuk orangtua siswa di Sekolah Dasar. Fokus kajian ini berupa: (1) Definisi PEP; (2) Penerapan PEP; (3) Manfaat PEP; (4) Pentingnya PEP di Sekolah Dasar

\section{METODE}

Teknik pengumpulan data atau informasi dalam penelitian ini yaitu menggunakan teknik studi pustaka dengan melakukan pencarian referensi yang relevan dengan permasalahan seperti buku, jurnal, artikel ataupun media elektronik. Penelitian ini menggunakan metode analisis data/informasi yang secara singkat pengertiannya yaitu proses dimana data/informasi diurutkan dengan suatu pola dan pengorganisasiannya menjadi suatu susunan data/informasi. Pola tersebut antara lain mengumpulkan data/informasi, menganalisis data/informasi, menarik kesimpulan, dan memaparkan hasil analisis. 


\section{Definisi PEP}

\section{PEMBAHASAN}

Parent Education Program sangat membantu pendidikan anak karena orangtua berfungsi sebagai fasilisator terhadap anak. Parenting education penting diadakan oleh pihak sekolah untuk memberikan pengetahuan bagi orangtua dalam melakukan sesuatu baik dirumah maupun lingkungan sekolah (Surbakti, 2012: 39 ). Tujuan pendidikan tidak dapat terwujud jika pendidikan hanya dilakukan di sekolah. Melalui kegiatan Parent Education in School akan terjalin interaksi yang baik antara orang tua dan sekolah sehingga program-program yang direncanakan dapat berjalan melalui syiar-syiar yang diberikan. Hal ini sangat sesuai dengan keterangan Ki Hajar Dewantara bahwa tujuan pendidikan tidak mungkin tercapai melalui satu jalur saja. (Ahmadi, 2014:171)

Parent Education Program adalah program yang bagi orang tua dalam pembentukan karakter anak. Pendidikan orangtua disini bukan hanya sekedar mengasuh anak, namun orang tua harus mendidik, membimbing dan melindungi setiap perkembangan anak. Parent Education Program sendiri memiliki pengertian yaitu program pendidikan pengasuhan yang dilakukan oleh lembaga guna meningkatkan kualitas kepengasuhan dan tercapainya visi-misi. Dalam proses pengawasan dan bimbingan, perlu adanya ilmu dan kemampuan yang cukup oleh orangtua. Perbedaan ilmu dan kemampuan yang dimiliki orang tua di setiap sekolah tentunya berbeda, maka proses pengawasan dan bimbingan orangtua kepada anak pun juga berbeda-beda dimana akan mempengaruhi pendidikan pada anak. Maka dari itu perlu adanya pelatihan bagi setiap orang tua anak agar memiliki pengetahuan dan kemampuan yang cukup untuk membimbing proses belajar anak dirumah. Banyak cara yang dilakukan untuk memberikan pelatihan kepada orang tua, salah satunya adalah Parent Education Program.

\section{Penerapan PEP}

Berdasarkan kajian yang telah kami lakukan bahwa terdapat beberapa sekolah dasar di Indonesia yang telah menerapkan Parent Education Program, bertumpu pada penelitian di SDIT SDIT Ar Raihan Bantul (Endarti, 2019), SDI Surya Buana Kota Malang(Lindasari, 2017) dan SD Insan Teratai (Septiani, 2016) masing - masing metode.

a. SDIT Ar Raihan Bantul

SDIT Ar Raihan Bantul merupakan sekolah pada jenjang sekolah dasar yang telah menerapkan Parent Education Program mulai tahun pelajaran 2017/2018. Parent Education Program di SDIT Ar Raihan Bantul diberinama Sekolah Orang Tua Ar Raihan (SOTA). Program ini diselenggarakan dengan tujuan menyamakan persepsi masing-masing orang tua tentang pendidikan anak di rumah dan di sekolah sehingga terbentuk sinergi bersama dalam mewujudkan tujuan pendidikan sesuai dengan visi dan misi sekolah, meningkatkan hubungan yang baik antara pihak sekolah dengan orangtua dan untuk memotivasi para wali murid dalam menangani setiap permasalahan yang terjadi pada anak.

Tripusat Pendidikan sebagai ajaran dari Ki Hajar Dewantara menjadi dasar dalam program Sekolah Orang Tua Ar Raihan dimana pusat pendidikan berada di, lingkungan keluarga, lingkungan sekolah dan lingkungan masyarakat. Kegiatan parenting Sekolah Orang Tua Ar Raihan (SOTA) bersifat wajib bagi orang tua siswa baru yang bernaung dibawah Yayasan Ar Raihan dari unit KBIT, TKIT, SDIT, dan SMPIT, kecuali yang sudah pernah mengikuti dan dinyatakan lulus pada jenjang sebelumnya.Kewajiban tersebut sesuai dengan perjanjian yang ditanda tangani oleh orang tua pada waktu mendaftar menjadi siswa baru di Yayasan Ar Raihan Bantul.

Kegiatan parenting SOTA hampir selalu dilaksanakan pada hari Sabtu. Hai ini dimaksudkan agar orang tua bisa lebih banyak yang hadir. Bentuk kegiatan SOTA 
pertama yaitu stadium general dengan peserta seluruh orang tua siswa baru dari tiap jenjang KB, TK, Sd dan SMP.

Metode yang digunakan dalam SOTA antara lain seminar dengan mendatangkan narasumber yang punya kompetensi di bidang sesuai tema yang dipilih, sedangkan untuk SOTA kelas kecil yang dilaksanakan di setiap unit menggunakan metode sharing, Tanya jawab dan juga penyampain materi. Sebelum kegiatan SOTA kelas kecil biasanya diawali dengan permainan/game-game dengan tujuan untuk membangkitkan semangat dari peserta yang sudah berperan sebagai orang tua. Metode yang dilakukan lebih banyak dengan komunikasi dua arah dengan harapan peserta akan dapat menyimpulkan sendiri dari apa yang sedang didiskusikan. Selain dilaksanakan secara tatap muka, ada satu materi yang sampaikan secara online melalui aplikasi WA group. Penanggungjawab kurikulum sebagai admin membuat group yang bersifat sementara, setelah kegiatan selesai group akan dibubarkan..

Parent Education Program melalui program SOTA sangat direspon positif oleh orangtua. Dari seluruh rangkaian kegiatan SOTA yang dilaksanakan secara berkesinambungan ditetapkan kriteria keberhasilan dengan indikator kehadiran peserta di setiap kegiatan minimal $75 \%$. Hal tersebut menunjukkan kesadaran orangtua akan pentingnya mengetahui pola asuh yang tepat terhadap anak sangat tinggu. Orangtua merasa sangat terbantu dengan adanya program SOTA, karena mendapatkan pelatihan bagaimana cara memberikan pendidikan yang benar kepada anak.

b. SD Surya Buana Malang

Kegiatan parenting di SDI Surya Buana Kota Malang dilaksanakan sejak tahun 2002, sehingga dapat diasumsikan bahwa partisipasi masyarakat yang dilaksanakan selama ini berjalan dengan baik. Tujuan dari parenting di SDI Surya Buana Malang sendiri adalah sebagai sarana untuk meningkatkan hubungan sekolah dengan orangtua dan untuk memotivasi para wali murid dalam menangani setiap permasalahan yang terjadi pada anak. Kegiatan parenting di SDI Surya Buana Malang meliputi bentuk program parenting yang terdiri dari dua bentuk yaitu bentuk formal (seminar) dan rutin (parent's day. Tujuan parent's day di SDI Surya Buana Malang senada dengan tujuan parenting seminar yaitu sebagai sarana untuk meningkatkan hubungan sekolah dengan orangtua dan untuk memotivasi para wali murid dalam menangani setiap permasalahan yang terjadi pada anak.

Pelaksanaan Parenting seminar di SDI Surya Buana Malang merupakan kerjasama sekolah dengan orangtua peserta didik dimana waktu pelaksanaan program ini dilaksanakan setiap satu tahun sekali bahkan bisa lebih dari satu kali dengan melibatkan seluruh yayasan yaitu orangtua peserta didik mulai dari jenjeng TK, SD, MTs, dan SMA. Selain itu, keterlibatan lainnya yaitu berasal dari tamu undangan yang sengaja diundang oleh pihak yayasan. Adapun pemateri yang mengisi acara tersebut berasal dari luar Kota yaitu Jakarta dan Surabaya yang ahli dalam memberikan materi mengenai parenting sehingga dapat memberikan manfaat tersendiri bagi sekolah, orangtua peserta didik, dan peserta didik. Parent's day dilaksanakan setiap minggu sekali tepatnya hari Sabtu dengan waktu sekitar 35 menit untuk satu kali pelaksanaan, adapun waktu 30 menit merupakan waktu yang diberikan untuk orangtua peserta didik yang belum sempat menyampaikan materinya. Sasaran program ini adalah peserta didik Kelas I, II, dan III, sehingga terdapat hal - hal yang perlu diperhatikan oleh orangtua peserta didik sebelum terlaksananya kegiatan yaitu seperti persiapan terhadap bahan materi yang akan disampaikan dan mental orangtua peserta didik itu sendiri. Materi yang disampaikan dalam pelaksanaan bertemakan bebas sehingga disesuiakan berdasarkan kemampuan masing - masing orangtua peserta didik, dan untuk materi yang sering disampaikan oleh orangtua peserta didik adalah bertemakan keterampilan. Adanya kegiatan ini mendapat respon yang baik dari peserta didik sendiri. 
Parenting parent's day dari wali kelas bersama beberapa orangtua. dimana materi yang dibahas kedua parenting adalah mengenai faktor pendukung, penghambat, dan strategi meminimalisasi hambatan. Hasil dari evaluasi parenting seminar yaitu pelaksanaan sudah berjalan dengan baik dan telah mencapai target dari sekolah itu sendiri, adapun evaluasi dilaksanakan melalui rapat panitia. Sedangkan hasil dari parenting parent's day yaitu pelaksanaan dirasa masih kurang maksimal karena masih banyaknya orangtua yang tidak hadir dalam pelaksanaan, adapun evaluasi tersebut dilakkukan dengan cara sharing antara wali kelas dengan orangtua peserta didik.

c. SD Insan Teratai Tangerang

Yayasan Insan Teratai sejati berdiri pada tahun 2009 berlokasi di Jalan Kalimati RT 012 Desa Gelam Jaya, Kecamatan Pasar Kemis, Tangerang Banten. Sekolah Dasar Insan Teratai telah menerapkan program parenting education yang telah dilaksanakan sejak tahun 2012. Pendidikan orangtua diterapkan di Insan Teratai bertujuan untuk memberikan pendidikan bagi orangtua dari kegiatan tersebt mampu menciptakan kerjasama. Kegiatan parenting education dilaksanakan satu bulan sekali tepatnya hari Sabtu minggu terakhir. Setiap satu bulan Sekolah Insan Teratai mengadakan kegiatan parenting education dengan tema yang berbeda dalam setiap pertemuan.

Kegiatan parenting education sebagai sarana transfer pengetahuan, nilai, sikap dan keterampilan kepada para orangtua terkait dengan pengasuhan anak. Parenting education mampu mentransfer mengenai pendidikan ramah anak kepada orangtua. Materi yang diberikan beragam mulai dari sosialisasi mengenai hak-hak anak, diskusi mengenai tips-tips mengasuh dan cara membangun hubungan baik dengan sekolah. Parenting education tidak hanya memberikan materi tentang perkembangan anak tetapi orangtua diberikan materi bagaimana bersikap saat berada di sekolah. Sekolah Insan Teratai mewajibkan orangtua untuk hadir dalam kegiatan parenting education karena kegiatan ini membantu orangtua dalam mengasuh anak dan memberikan wawasan yang luas.

Model yang digunakan dalam kegiatan parenting education disekolah Insan Teratai itu menggunakan model ceramah, model diskusi, Tanya jawab dan home visit. Hal ini dilakukan agar antara pembicara dan orangtua dapat berinteraksi dengan baik. Selain itu model tersebut mempermudah orang tua memahami materi yang disampaikan oleh pembicara. Pembicara akan melakukan beberapa model pembelajaran sesuai dengan materi parenting dan melakukan beberapa variasi pembelajaran agar proses pembelajaran tidak membosankan.

Kegiatan parenting education memiliki manfaat bagi orangtua maupun pihak sekolah. Kegiatan parenting education sangat berguna bagi orangtua karena membantu para orangtua dalam mendidik anak. Kegiatan parenting education mendapatkan respon yang baik dari orangtua karena kegiatan ini sangat membantu orangtua dalam mendidik anak dirumah. Orangtua juga mendapatkan pengetahuan dan wawasan untuk mengasuh anak melalui kegiatan parenting education. Pada kegiatan parenting education orangtua lebih aktif dan bisa menyampaikan pendapat dalam hal mengasuh anak. selain itu orangtua bersikap baik dan sangat berantusias dalam mengikuti kegiatan parenting education. Kagiatan parenting education di SD Insan Teratai mampu menciptakan keharmonisan sekolah karena disini orangtua berkumpul dan saling berpendapat.

Pendidikan orangtua di SD Insan Teratai telah memberikan dampak positif bagi orangtua, guru dan kepala sekolah karena kegiatan ini mampu mempererat hubungan satu sama lain. Keharmonisan yang tercipta di sekolah Insan Teartai memberikan manfaat bagi anak salah satunya anak mendapatkan kenyamanan saat berada di sekolah. sekolah yang tidak harmonis kepada orangtua akan memiliki hubunganyang buruk dan anak menjadi tidak semangat belajar. 
Kendala yang dialami dalam kegiatan parenting education kurangnya kerja sama antara pihak sekolah dan orangtua sehingga menyebakan komunikasi yang tidak baik. Komunikasi yang kurang antara pihak sekolah dan orangtua akan menimbulkan hubungan yang kurang baik. Keterbatasan pengetahuan orang tua atau peserta parenting education juga manjadi salah satu kendala yang mendasar terhadap terselanggaranya kegiatan parenting education dan orang tua juga lebih lama untuk memahami materi yang disampaikan oleh pembicara.

Berdasarkan penerapan Parent Education Program SDIT Ar Raihan Bantul, SD Surya Buana Malang dan SD Insan Teratai Tangerang dapat berjalan dengan sangat baik. Parent Education Program sangat disambut baik oleh orangtua anak. Orangtua merasa sangat terbantu dengan adanya program tersebut karena dapat memberikan pengetahuan bagaimana mendidik anak saat di rumah dengan baik. Dari program ini mampu meningkatkan komunikasi antar pihak sekolah dengan orangtua anak, sehingga terwujudnya pendidikan anak yang baik dan tidak tumpang tindih. Permasalah - permasalahan mengenai keterhambatan pendidikan anak akan terselesaikan dengan adanya kerjasama antara pihak sekolah dan orang tua anak. Keseimbangan dalam mendidik anak akan tercapai.

\section{Manfaat PEP}

Manfaat Parent Education Program sesuai dengan pendapat Harahap (2012) yang mengemukakan manfaat dari Parenting yaitu: (1) terjalinnya mitra kerja lintas sektor, misalnya dari pengusaha yang berkaitan dengan produk yang berkaitan dengan kebutuhan tumbuh kembang anak, instansi pemerintah, dan penerbitan buku; (2) terpenuhinya kebutuhan hak-hak anak; (3) berkembangnya rasa percaya diri orangtua dalam mendidik anak; (4) terjalinnya hubungan yang harmonis pada masing-masing anggota keluarga dengan tugasnya masing-masing; (5) terciptanya hubungan antara keluarga di lingkungan masyarakat sekitar lembaga pendidikan; dan (6) terjalinnya mitra kerja sesama anggota parenting.

Parent Education Program perlu dilaksanakan oleh orangtua karena memiliki banyak manfaat yang didapatkan, antara lain:

a. Terjalinnya hubungan yang baik antara sekolah dan orangtua

Parent Education Program akan meningkatkan hubungan yang baik antara pihak sekolah dan orang tua. Pihak sekolah bekerjasama dengan orangtua dengan memberikan pelatihan bagaimana mendidik anak saat di rumah.

b. Meningkat wawasan pengetahuan orangtua

Setelah melaksanakan program Parent Education Program diharapkan pengetahuan orang tua semakin bertambah. Orang tua bisa mengetahui dan menguasai materi yang anak pelajari disekolah, sehingga ketika anak belajar dirumah, orang tua dapat membantu mengajarkan materi tersebut kepada anak ketika anak masih belum paham terhadap materi tersebut.

c. Meningkatkan kualitas pola asuh terhadap anak

Parent Education Program diharapkan akan memberikan pengetahuan baru kepada orangtua bagaimana cara pola asuh yang baik untuk diterapkan saat dirumah. untuk mengajar anak melaksanakan kegiatan belajar dirumah, perlu dilakukan pendekatan agar membuat anak merasa senang dalam melaksanakan kegiatan belajar dirumah. pendekatan tersebut penting dilakukan dengan menggunakan pola asuh yang baik dan tepat. Parent Education Program akan membantu orangtua dalam meningkatkan pengawasan dan bimbingan untuk meningkatkan kualitas belajar anak dirumah.

d. Meningkatkan rasa percaya diri orangtua

Orang tuaakan merasa lebih percaya diri setelah mengikuti Parent Education Program karena merasa lebih memiliki pengetahuan dan kemampuan yang cukup untuk mengawasi dan membimbing anak dalam meningkatkan kualitas belajar 
anak dirumah. orang tua tidak akan merasa ragu lagi dalam membimbing anak dalam belajar.

e. Meningkatkan kualitas belajar anak dirumah

Salah satu manfaat dari program Parent Education Program adalah meningkatkan kualitas belajar anak di rumah. Kualitas belajar anak di rumah tidak hanya dilihat dari kemampuan dari anak itu sendiri, melainkan kemampuan orangtua juga sangat mempengaruhi kualitas belajar anak di rumah. Ketikan orangtua memiliki cukup pengetahuan dan kemampuan dalam mengawasi dan membimbing anak dalam belajar, maka kegiatan belajar yang dilaksanakan oeh anak akan menjadi berkualitas.

f. Meningkatkan hasil belajar anak di sekolah

Saat kualitas belajar anak dirumah sudah tercapai dengan baik, sehingga anak lebih memahami pembelajaran yang dilakukan saat disekolah. Secara tidak langsung, kualitas belajar anak akan mempengaruhi prestasi anak ketika disekolah. Semakin baik kualitas belajar anak di rumah maka pemahaman akan materi lebih terkuasai dan secara tidak langsung akan meningkatkan prestasi anak di sekolah. keberhasilan restasi anak tersebut karena didukung oleh proses pembelajaran yang baik disekolah serta kegiatan belajar yang berkualitas saat dirumah. Setelah anak melaksanakan kegiatan belajar di rumah dengan pengawasan dan bimbingan orang tua yang berkualitas, diharapkan mampu meningkatkan hasil belajar anak di sekolah.

\section{Pentingnya Penerapan PEP}

Parent Education Program telah menunjukkan keberhasilan dalam memberikan pelatihan kepada orangtu diibuktikan dengan tingginya tingkat partisipasi orang tua dalam mengikuti program Parent Education Program di SDIT Ar Raihan Bantul, SD Surya Buana Malang dan SD Insan Teratai Tangerang. Antusisame peserta ditunjukkan dalam peran aktif saat pelaksanaan kegiatan baik secara tatap muka dan secara online (Endarti, 2019). Adanya kegiatan ini mendapat respon yang baik dari peserta didik sendiri(Lindasari, 2017).Pendidikan orangtua di SD Insan Teratai telah memberikan dampak positif bagi orangtua, guru dan kepala sekolah karena kegiatan ini mampu mempererat hubungan satu sama lain (Septiani, 2016).

Parent Education Program School perlu diterapkan di semua jenjang sekolah, terutama sekolah dasar. Masih terdapat beberapa masalah pada orangtua apabila tidak ditindaklanjuti akan menghambat pendidikan anak. Orang tua selalu mempunyai pengaruh yang paling kuat pada anak-anak. Setiap orang tua mempunyai gaya tersendiri dalam hubungannya dengan anak-anaknya, dan ini mempengaruhi perkembangan sosial anak. Pola asuh yang berbeda-beda berkaitan erat dengan sifat kepribadian yang berbeda-beda pada setiap anak. Maka dari itu Parent Education Program perlu diterapkan sebagai solusi atas permasalahan keterbatasan pengetahuan orangtua dalam mendidik anak di rumah. Hal tersebut sesuai dengan pendapat Surbakti (2012:39) yang mengemukakan bahwa Parenting education penting diadakan oleh pihak sekolah untuk memberikan pengetahuan bagi orangtua dalam melakukan sesuatu baik dirumah maupun lingkungan sekolah.

\section{SIMPULAN}

Beberapa simpulan dari kajian ini adalah sebagai berikut:

1. Parent Education Program merupakan program yang bagi orang tua dalam pembentukan karakter anak yang dilakukan oleh lembaga untuk meningkatkan kualitas kepengasuhan dan tercapainya visi-misi.

2. Penerapan Parent Education Program telah diterapkan di beberapa Sekolah Dasar yaitu SDIT Ar Raihan Bantul, SD Surya Buana Malang dan SD Insan Teratai Tangerang yang terbukti keberhasilan dengan tingginya tingkat partisipasi orangtua dalam mengikuti Parent Education Program 
3. Manfaat Parent Education Program adalah menjalin hubungan yang baik antara sekolah dan orangtua, meningkatkan pengetahuan orangtua dan meningkatkan percaya diri orangtua

4. Parent Education Program penting diimplementasikan pada banyak Sekolah Dasar yang belum melibatkan orangtua dalam pendidikan anak secara langsung.

\section{DAFTAR PUSTAKA}

Afrianto, (2011). Orangtua cermat, anak sehat . Jakarta: Trans Media.

Ahmadi, R. (2014). Asas dan filsafat pendidikan. Yogyakarta: Ar-Rum Media

Cholifah, T.N. (2016) Pengaruh Latar Belakang Tingkat Pendidikan Orangtua Dan Gaya Belajar Terhadap Hasil Belajar Siswa Pada Kelas IV SDN Kecamatan Sananwetan Kota Blitar. Jurnal Pendidikan. Vol. 1 No. 3, Thn 2016, Halaman 486-491.

Endarti, T.D. Sunarto. (2019). Program Parenting Melalui Sekolah Orang Tua di Sekolah Dasar. Media Manajemen Pendidikan. Volume 2 No. 1 Februari 2019.

Harahap, M. (2012). Manajemen parenting dalam meningkatkan hubungan sekolah dengan orang tua. Manajemen dan Supervisi Pendidikan. Vol.1 No.2 halaman146-155.

Ilahi, M.T. (2013). Quantum Parenting: Kiat Sukses Mengasuh Anak Secara Efektif dan Cerdas. Jogjakarta: Kata Hati.

Lindasari, E. dkk. (2017). Manajemen Parenting dalam Meningkatkan Hubungan Sekolah dengan Orangtua. 146 Manajemen dan Supervisi Pendidikan, Volume 1, Nomor 2 Maret 2017: 146 - 155.

Peraturan Menteri Pendidikan dan Kebudayaan. (2015). Permendikbud RI Nomor 23 Tahun 2015 tentang Penumbuhan Budi Pekerti. Jakarta : Permendikbud.

Persada, N V dkk. (2017). Perlibatan Orang Tua pada Pendidikan Anak di SD Sains Islam Al Farabi Sumber Cirebon. Universitas Negeri Semarang. Diunduh dari http://journal.unnes.ac.id/sju/index.php/eduman/article/download/22774/10742. Diunduh pada tanggal 23 Juli 2019

Septiani, F. (2016). Peranan Pendidikan Orangtua (Parenting Education) dalam Menciptakan Keharmonisan Sekolah (Studi Deskriptif Kualitatif di SD Insan Teratai). Banten: Sekolah Tinggi Agama Buddha Negeri Sriwijaya Tangerang Banten.

Surbakti, E. B. (2012). Parenting anak-anak. Jakarta: PT. Elex Media.

Syamsudduha, St., dan Dion Ginanto, (2016) Parental Involvement in Indonesia: A study on two Public Schools in Makassar, Yogyakarta: UNY Advances in Social Science, Education and Humanities Research (ASSEHR), volume 66 1st Yogyakarta International Conference on Educational Management/Administra tion and Pedagogy (YICEMAP)

Tanta. (2010). Pengaruh Gaya Belajar Terhadap Hasil Belajar Mahasiswa pada Matakuliah Biologi Umum Program Studi Pendidikan Biologi Universitas Cenderawasih. Jurnal Kependidikan Dasar, 1 (1):1-15.

Undang-Undang RI No. 20 Tahun 2003 Tentang Sistem Pendidikan Nasional Tahun 2003. Jakarta: CV. Mini Jaya Abadi. 